\title{
An Investigation on Mechanical Properties and Damping Behaviour of Hardened Mortar with Rubber Tire Crumbs (RTC)
}

\author{
Restu Faizah ${ }^{1, *}$, Henricus Priyosulistyo ${ }^{2}$, and Akhmad Aminullah ${ }^{3}$ \\ ${ }^{1} \mathrm{Ph} . \mathrm{D}$ Student of the Department of Civil and Environmental Engineering, Universitas Gadjah Mada, Yogyakarta, Indonesia \\ ${ }^{1}$ Staff member of the Department of Civil Engineering, Universitas Muhammadiyah Yogyakarta, Indonesia \\ ${ }^{2}$ Professor of the Department of Civil and Environmental Engineering, Universitas Gadjah Mada, Yogyakarta, Indonesia \\ ${ }^{3}$ Staff member of the Department of Civil and Environmental Engineering, Universitas Gadjah Mada, Yogyakarta, Indonesia
}

\begin{abstract}
Masonry wall has been used for ages as a part of non-engineered building structures, due to its ease of manufacture, strength, and stiffness to support gravity loads, but brittle enough to resist earthquake shake. One solution to increase its ductility when the earthquake shake stroked, ductile materials at bed joints that binding the masonries may apply. Mortar is a composite material consisting of sands, cement, and water that is generally used for masonry construction as a binder at bed joints. On the other hand, rubber has been used to isolate vibration of machinery because of its good damping behaviours. Those materials will be mixed and be elaborated to provide a ductile mortar binder at bed joints. This research aims to investigate the mechanical properties and the damping behaviour of hardened mortar with rubber tire crumbs at proportions of $0 \%, 40 \%$, and $60 \%$. Three types of specimens in forms of mortar cubes of $50 \times 50 \times 50 \mathrm{~mm}^{3}$, tensile specimens and mortar beams of $100 \times 100 \times 500 \mathrm{~mm}^{3}$ were tested to provide strength and damping behaviour. The addition of rubber tire crumbs in the mortar decreased the compressive strength, tensile strength, flexural strength and unit weight. Despite its weakness in the mechanical strengths, the addition of rubber tire crumbs could increase the damping behaviour significantly. This research recommended that mortar containing RTC is still appropriate use for non-structural component although it has low mechanical properties.
\end{abstract}

\section{Introduction}

Earthquake is an unpredictable natural phenomenon causing damage to houses/ buildings, roads, bridges and other infrastructures. The damage wall due to earthquake affects casualties and injuries, especially for masonry wall of houses in earthquake-prone areas. It is mostly caused by the poor quality of materials and poor workmanship, resulting in, among others poor detailing, poor mortar quality, poor concrete quality, and poor brick laying [1].

Currently, waste of rubber tire in form of rubber crumb is used as a replacement material in concrete mix or material pavement mix. The previous study reported that replacement of partial aggregate in concrete with waste of rubber tire affect the concrete properties. It produces lightweight concrete $[2,3]$, increases workability [4], ductility [5] and damping ratio [6,7], but mechanical properties $[2,3,4,8,9,10]$. These properties confirm a conclusion that concrete with rubber tire crumb (RTC) is more appropriately used as a non-structural component that doesn't support higher tension and compression. The lightweight properties, good ductility and damping behaviour, has been taken into consideration in using concrete with RTC as a structural member against large earthquake.

Based on these realities, innovation is needed to improve the resilience of houses against earthquake by taking adavantage of rubber crumb which improves workability of mortar, instead of low prices, easy to access, and high damping. The innovation may be applicable for middle to the low-class economics people. The waste of rubber tire is overabundance, has limited utilization and has been an environmental problem.

This study investigates mechanical properties and damping behaviour of hardened mortar with RTC. It is a preliminary study in proposing the utilization of RTC as mortar bed joint on masonry wall to increase damping behaviour of the wall, in preventing sudden collapse.

* Corresponding author: restu.faizah@umy.ac.id 


\section{Experimental Program}

\subsection{Material Properties}

This hardened mortar consists of Pozzolanic Portland Cement (PPC), sand, water and RTC. The sand, taken from Cangkringan Sleman, has specific gravity of 2.745 and unit weight of $1.508 \mathrm{~kg} / \mathrm{m}^{3}$, while RTC has specific gravity of 1.16 and unit weight of $235.7 \mathrm{~kg} / \mathrm{m}^{3}$. This RTC passed over sieve no. 16 (\#1.18 mm).

Material requirements are determined by absolute volume methods to obtain mix mortar having cement to sand ratio of $1: 3,1: 4$ and $1: 5$, while RTC contents are of $0 \%, 40 \%$ and $60 \%$ of the sand requirement respectively.

\subsection{Specimens Preparation}

Three types of the specimens in forms of mortar cubes of $50 \times 50 \times 50 \mathrm{~mm}^{3}$, tensile specimens and mortar beams of $100 \times 100 \times 500 \mathrm{~mm}^{3}$ were used in this study. The mortar cubes and tensile specimens were tested to provide compressive and tensile strengths, whereas mortar beams were tested to investigate the flexural strengths and damping behaviour. A total of 45 mortar cubes, 45 mortar briquette specimen and 9 mortar beams were tested. The distribution of the specimens is shown in Table 1.

Water requirement was determined by ASTM C230/C230M-08 (Standard Specification for Flow Table for Use in Tests of Hydraulic Cement) [11] to comply the appropriate flow for workmanship. Furthermore, fresh mortar was moulded and cured until 28 days of old.

Table 1. Distribution of specimens

\begin{tabular}{|c|c|c|c|c|c|}
\hline \multirow{2}{*}{$\begin{array}{c}\text { Cement } \\
\text { to } \\
\text { Sand } \\
\text { Ratio }\end{array}$} & \multirow[b]{2}{*}{ Code } & \multirow[b]{2}{*}{$\begin{array}{c}\text { RTC } \\
\text { Content }\end{array}$} & \multicolumn{3}{|c|}{$\begin{array}{c}\text { Types and Number of } \\
\text { Specimens }\end{array}$} \\
\hline & & & $\begin{array}{l}\tilde{d} \\
\hat{\Xi}\end{array}$ & 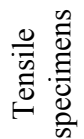 & 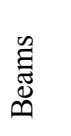 \\
\hline \multirow{3}{*}{$1: 3$} & I & $0 \%$ & 5 & 5 & \\
\hline & II & $40 \%$ & 5 & 5 & \\
\hline & III & $60 \%$ & 5 & 5 & \\
\hline \multirow{3}{*}{$1: 4$} & IV & $0 \%$ & 5 & 5 & 3 \\
\hline & V & $40 \%$ & 5 & 5 & 3 \\
\hline & VI & $60 \%$ & 5 & 5 & 3 \\
\hline \multirow{3}{*}{$1: 5$} & VII & $0 \%$ & 5 & 5 & \\
\hline & VIII & $40 \%$ & 5 & 5 & \\
\hline & IX & $60 \%$ & 5 & 5 & \\
\hline
\end{tabular}

\subsection{Experimental Set-up}

\subsubsection{Compressive and Tensile Strength Test}

Mortar compressive strength test (Figure 1a) was carried out by ASTM C109/C 109M-07 (Standard Test Method for Compressive Strength of Hydraulic Cement Mortars (Using 2-in. or [50-mm] Cube Specimens) [12]. Mortar tensile strength was tested (Figure 1b) according to ASTM C190-85 (Method of Test for Tensile Strength of Hydraulic Cement Mortars) [13].

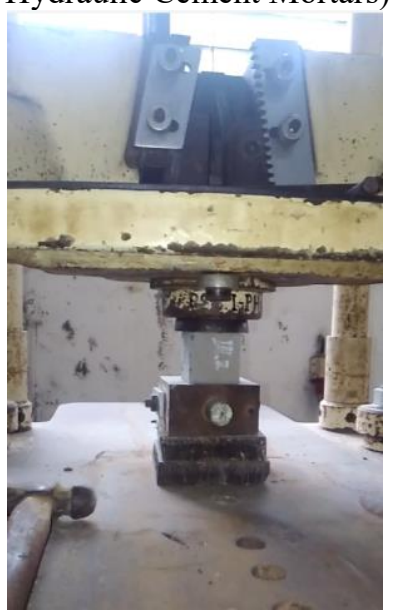

a) Compressive strength test

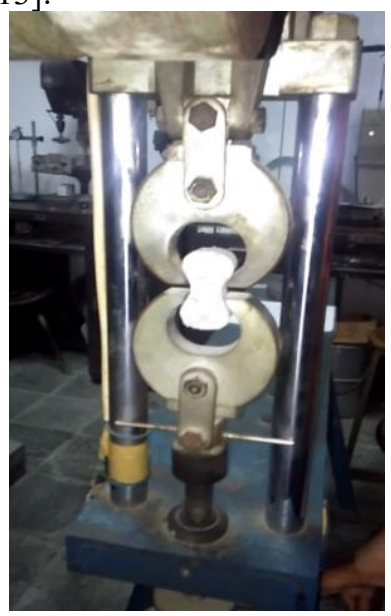

b) Tensile strength test
Fig. 1. Mortar testing set-up

\subsubsection{Damping Behaviour Test}

To investigate damping behaviour of hardened mortar, a simple laboratory setup was provided. The beam specimen was clamped at one end and free on the other end. A load of $15 \mathrm{~N}(1.5 \mathrm{~kg})$ on the free end was hanged by a string. When the string was cut, the beam generated a free vibration on its fundamental frequency. A sensor (accelerometer) installed on the free end of beam recorded the vibration. Furthermore, the Dewesoft Program, installed in the computer, converted the analog into digital signals and transformed them into frequency domain (FFT). Figure 2 shows an experimental set-up of damping test.

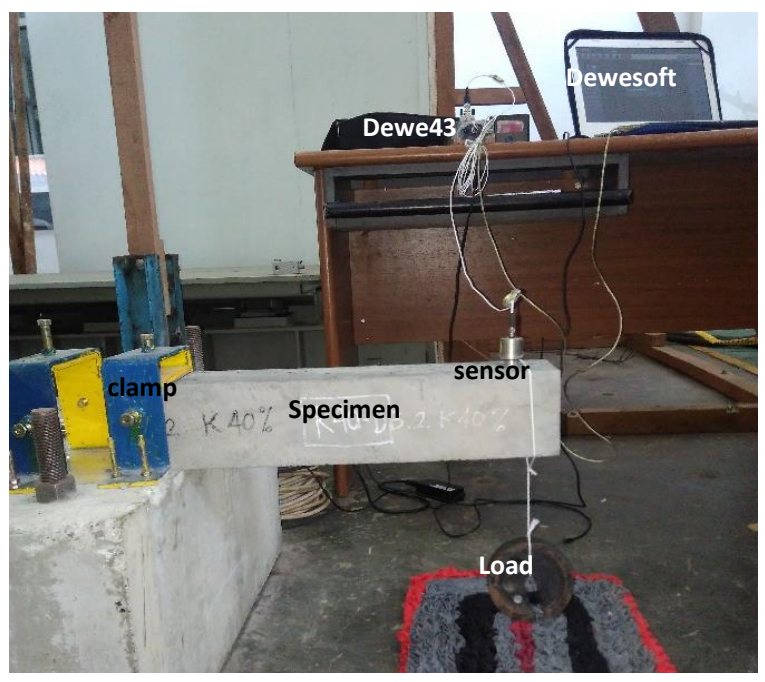

Fig. 2. Experimental set-up of damping test 
Damping behaviour of the beam can be identified by analyzing the vibration arising from cutting of the string using the logarithmic decrement method as explained in Equation 1 and Figure 3.

$$
\xi=\operatorname{Ln}\left[\frac{Y_{1}}{Y_{2}}\right] \times 100 \times \frac{1}{N \times 2 \pi}
$$

\section{(1)}

where,

$\xi$ : Damping ratio $(\%)$

$\mathrm{Y}_{1}$ : Amplitude 1 (maximum)

$\mathrm{Y}_{2}$ : Amplitude 2 (approximately at a half of $\mathrm{Y}_{1}$ )

$\mathrm{N}$ : The number of cycles between $\mathrm{Y}_{1}$ and $\mathrm{Y}_{2}$

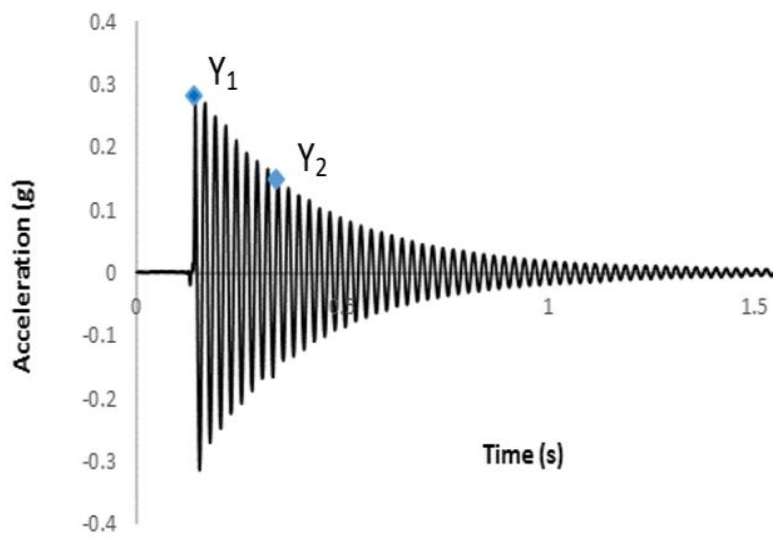

Fig. 3. The logarithmic decreament signal at the free end of the beam

\subsubsection{Flexural Strength Test}

The beam specimens were tested by flexural strength test after damping behaviour was investigated, as shown in Figure 4. The test applies load-unload systems to investigate the beam's resistance to repeated loading. LVDT connected to the data logger detects the deflection of the beam during observation.

\section{Result and Discussion}

\subsection{Mechanical Properties}

\subsubsection{Unit Weight}

The mortar cubes containing $40 \%$ and $60 \%$ of RTC have a unit weights of $1638-1772 \mathrm{~kg} / \mathrm{m}^{3}$ and $1467-1516$ $\mathrm{kg} / \mathrm{m}^{3}$ respectively, whereas the unit weight of normal mortar is $2148-2228 \mathrm{~kg} / \mathrm{m}^{3}$ (see Figure 5). This result indicate that the addition of RTC may reduce the unit weight of the mortar cubes by up to $22 \%$ for $40 \%$ RTC content and $32 \%$ for $60 \%$ RTC content. Besides that, the unit weights of the mortar cubes containing of $40 \%$ and
$60 \%$ RTC can classify as a lightweight mortar because the unit weight is less than $1850 \mathrm{~kg} / \mathrm{m}^{3}$ as required by SNI 03-2461-2002 [14].

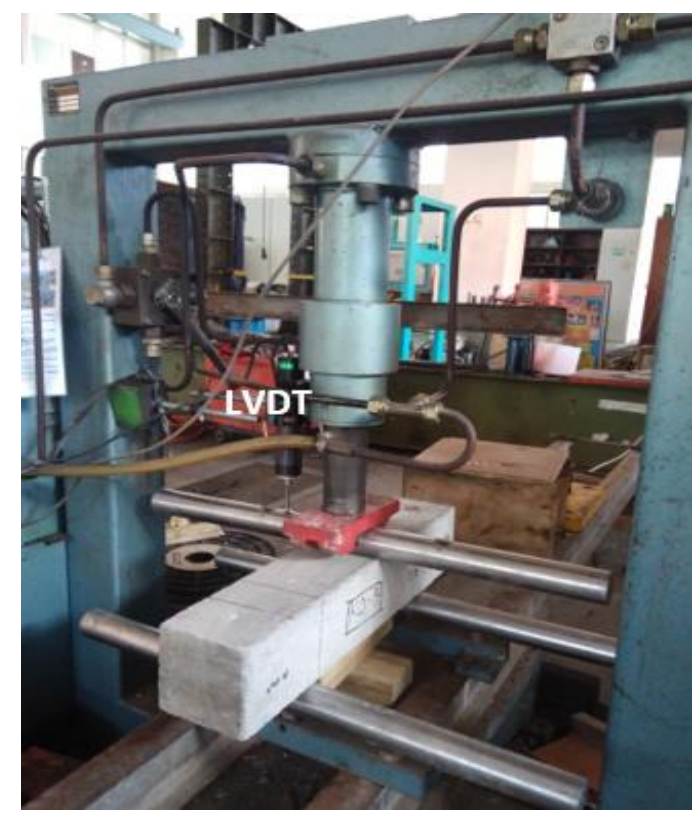

Fig. 4. Flexural strength testing set-up

The unit weight of RTC replacing the sand caused the decrease of unit weight of mortar with RTC. The specific gravity of RTC is 1.1597 and 2.74 for sand, while the respective unit weight is $1508 \mathrm{~kg} / \mathrm{m}^{3}$ and $235.72 \mathrm{~kg} / \mathrm{m}^{3}$.

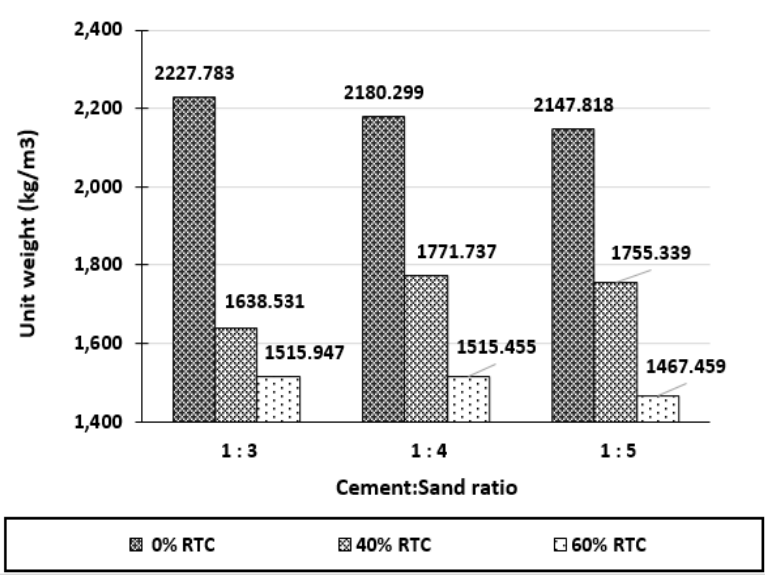

Fig. 5. The unit weight of the hardened mortar

\subsubsection{Compressive and Tensile Strength}

The results of the compressive and tensile strength test shown in Figure 6 and 7 conclude that the addition of RTC in the mortar-mixture results in decreasing compressive and tensile strengths of the hardened mortar. Due to its low compressive and tensile strength, the mortar containing RTC may be recommended for use as a non-structural material, resisting low axial forces. 
The mortar cubes containing 40\% and 60\% RTC had compressive strengths of $22 \%-35 \%$ and $13 \%-19 \%$ respectively in comparison to normal mortar. The lowest compressive strength was $2.681 \mathrm{MPa}$ for $60 \% \mathrm{RTC}$. This value meets the minimum compressive strength requirement of masonry bricks of $2.5 \mathrm{MPa}$ [3], so it can be recommended for use of mortar bed joint, since the compressive strength of masonry walls is more influenced by the strength of the mortar bed joint, and is limited by the strength of the masonry brick. Sometimes the addition of mortar strength hasn't significant changes in increaseing the compressive strength of masonry walls [15].

The decrease in tensile strength due to the addition of RTC on the mortar is smaller than the decrease in compressive strength. This fact supports the state that RTC is more advantageous in tensile strength than in compressive strength.

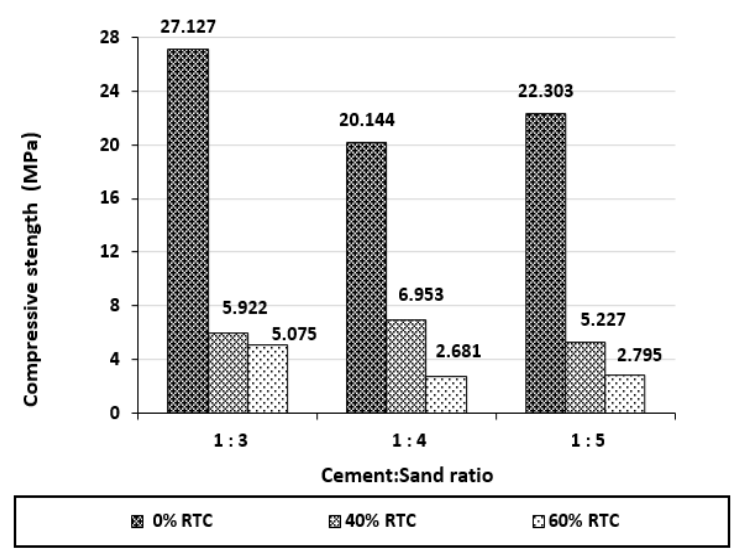

Fig. 6. The compressive strength test result

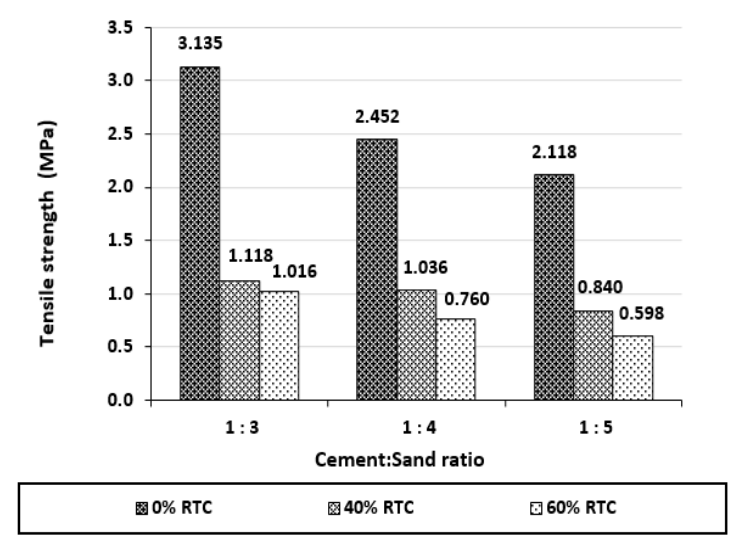

Fig. 7. The tensile strength test result

\subsubsection{Flexural Strength}

The addition of RTC in the mortar-mixture also resulted in decreasing the flexural strength but the maximum displacement of hardened mortar as shown in Figure 8. The specimens with $40 \%$ and $60 \%$ RTC content had $67 \%$ and $41 \%$ decreasing of the flexural strength, while the maximum displacement increases up to $203 \%$ and $400 \%$ respectively. This trend also took place on repeated loading as presented in Figure 9.

By referring these results, it could be estimated that mortar containing RTC had a ductile property as indicated by its ability to prevent a sudden collapse. This property may be appropriately applied as earthquake structural materials because of its ductile property against earthquake. It is expected that the occupants have enough time to exit the building before the building collapsed.

Topcu, 2018 [16] also investigate the flexural strength of concrete with RTC. He stated that using rubber aggregate reduces the flexural strength of concretes. Even though rubber particles decrease the flexural strength of concrete, RC specimens do not collapse suddenly under bending load during the flexural test due to high deformations of rubber particles. Figure 8 and 9 show that deflection of the mortar with RTC is expected larger than normal mortar.

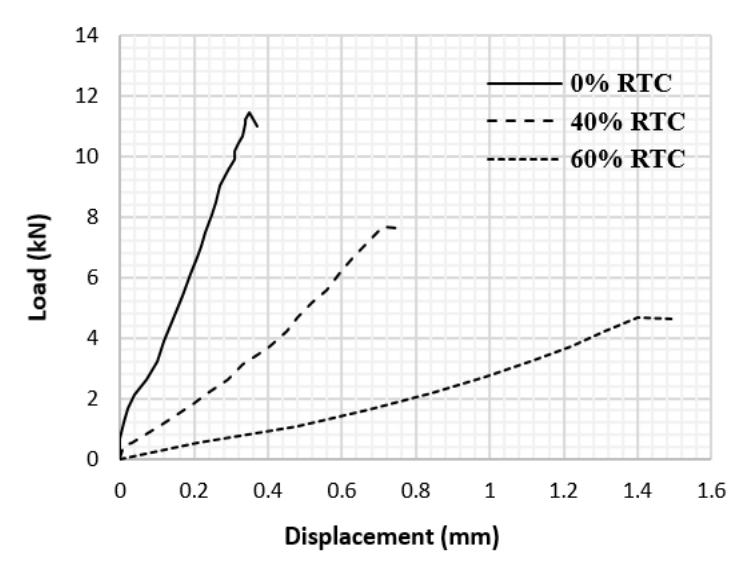

Fig. 8. Load-Displacement relationship (single-load system)

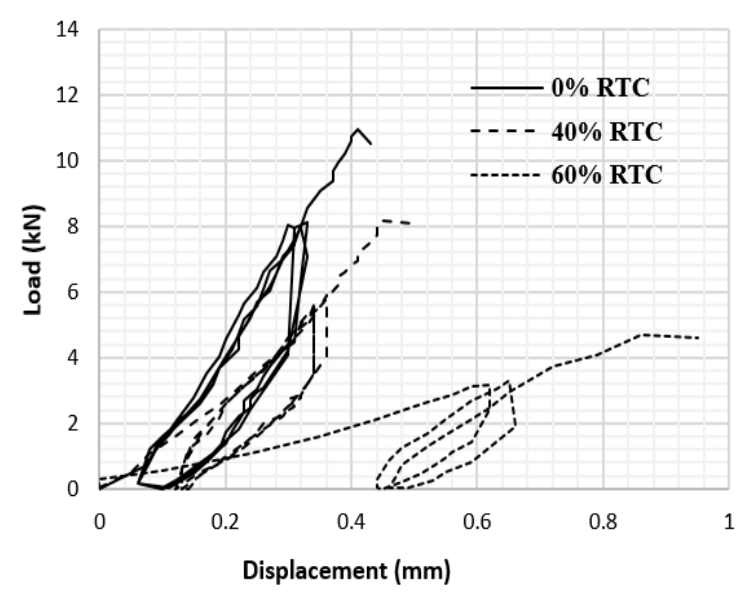

Fig. 9. Load-displacement relationship (load-unload system) 


\subsection{Damping Behaviour}

The result from damping test (Figure 10 and 11) showed that the addition of RTC in the mortar-mixture reduced the frequency but increased the damping ratio. The mortar beam frequency decreased as much as $14.7 \%$ and $29.5 \%$, while the damping ratio increased as of $40 \%$ and $75 \%$ (in comparison to normal mortar beam) for a beam containing $40 \%$ and $60 \%$ RTC respectively.

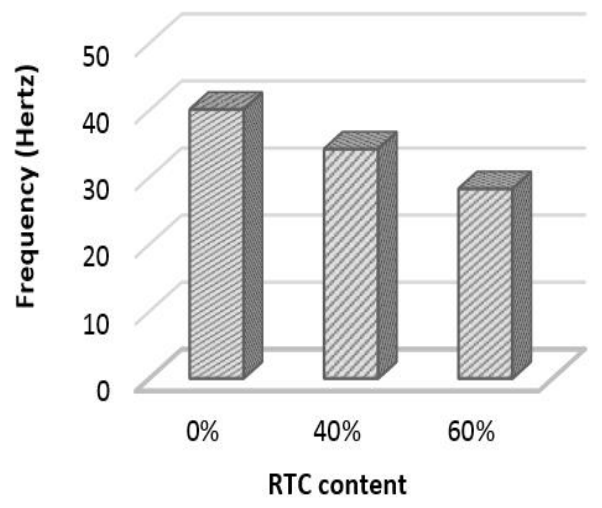

Fig. 10. Frequency of mortar beams

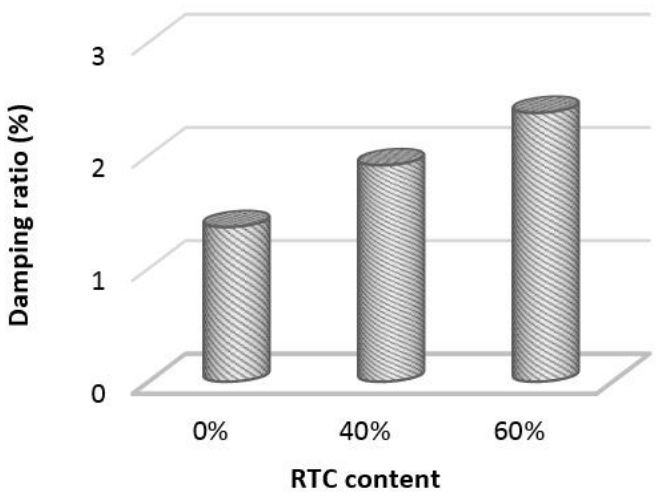

Fig. 11. Damping ratio of mortar beams

The decreased frequency of beam indicates the decreased rigidity of beam due to the presence of RTC in the mortar mixture. Because of the impermeable characteristic of the rubber, the bonding among the cement paste and rubber in the mixture is not as good as cement paste and sand. The lack of bonding can affect the hardened mortar properties to be porous and not rigid, but high damping ability.

This high damping ability was assumed to be due to an increase of friction among the rubber particles, the sand and the cement paste in the mixture. It can be verified by visual observations, as shown by the higher density of normal beams in comparison to the beam containing RTC, as a result from poor adhesiveness between RTC with sand and cement paste.
The damping behaviour of mortar beam with RTC inspire new expectation to get more earthquake resistant building by using material having high damping ability. It should be considered that mortar with RTC has low mechanical strength, so it is not recommended for use on structures withstanding large axial loads.

This damping ratio can be upgraded by increase the rubber dimension since the damping ratio of rubber mortar not only be influenced by the rubber content but also affected by the rubber dimension [17].

\section{Conclusion}

From the analysis of the mechanical properties and the damping behaviour, it concludes that:

1. The addition of RTC in mortar can improve the damping ratio of hardened mortar significantly, but the mechanical characteristis.

2. Mortar containing RTC is still appropriate use for non-structural component although it has low mechanical properties.

3. Based on the damping behaviour, mortar containing RTC is recommended for improving performance of masonry wall against earthquake shake.

\section{Further Research}

Based on this research, it is suggested for some further researches. A similar research using larger RTC might increase the damping ratio of hardened mortar with RTC. It may also be necessary to examine the effects of long-time deformation due to creep.

The authors express their gratitude and highest appreciation to Lembaga Pengelola Dana Pendidikan (LPDP) from Ministry of Finance who has given Beasiswa Unggulan Dosen IndonesiaDalam Negeri (BUDI-DN) scholarship.

\section{References}

1. T. Boen, Challenges and Potentials of Retrofitting Masonry Non-Engineered Construction in Indonesia, Kyoto University, Kyoto Japan, (2014)

2. D. Sadek and M. El-Attar, Structural Behavior of Rubberized Masonry Walls, J. of Clr. Prod. 89, 174186. (2015)

3. I. Satyarno, Pengaruh Penggunaan Serutan Karet Ban Bekas untuk Campuran Beton (in Bahasa), Med. Tek. XXVIII, 4, 45-51 (2006)

4. Z. Boudaoud and M. Beddar, Effects of Recycled Tires Rubber Aggregates on the Characteristics of Cement Concrete, OJ. of Civ. Eng.-Sci. Resch, 2, 193-197 (2012)

5. N. Oikonomou and S. Mavridou, The Use of Waste Tyre Rubber in Civil Engineering Works, in Sustainability of construction materials, Greece, 213-238 (2009) 
6. O. Youssf, M. A. ElGawady and J. E. Mills, Experimental Investigation of Crumb Rubber Concrete Columns under Seismic Loading, J. Struct. 15 (2015)

7. L. Zheng, X. Huo and Y. Yuan, Experimental Investigation on Dynamic Properties of Rubberized Concrete, Constr. \& Build. Matrls, 22, 939-947 (2008)

8. R. Siddique and T. Naik, Properties of Concrete Containing Scrap - Tire Rubber - an Overview, Wast. Manag. 24, 563-569 (2004)

9. A. Yilmaz and N. Degirmenci, Possibility of Using Waste Tire Rubber and Fly Ash with Portland Cement as Construction Materials, J. Wast. Manag. 29, 1541-1546 (2009)

10. M. Batayneh, I. Marie and I. Asi, Promoting the Use of Crumb Rubber Concrete in Developing Countries, J. Wast. Manag., 28, 2171-2176 (2008)

11. ASTM International, ASTM C230/C230M-08: Standard Specification for Flow Table for Use in Tests of Hydraulic Cement, United States (2008)

12. ASTM International, ASTM C109/C 109M-07: Standard Test Method for Compressive Strength of Hydraulic Cement Mortars (Using 2-in. or [50-mm] Cube Specimens), United States (2007)

13. ASTM International, ASTM C190-85: Method of Test for Tensile Strength of Hydraulic Cement Mortars, United States (1985)

14. Badan Standardisasi Nasional (BSN), SNI 03-24612002: Spesifikasi Agregat Ringan untuk Beton Ringan Struktural (in Bahasa), Indonesia (2002)

15. Wisnumurti, A. Soehardjono, and K. A. Palupi, Optimalisasi Penggunaan Komposisi Campuran Mortar terhadap Kuat Tekan Dinding Bata Merah (in Bahasa), J. Rek. Sip. (1) 1, 25-32 (2007)

16. I. B. Topcu and A. Unverdi, Scrap Tires/Crumb Rubber, Waste and Supplementary Cementitious Materials in Concrete, Elsevier Ltd, 51-77 (2018)

17. L. Zheng, X. Huo, and Y. Yuan, Experimental Investigation on Dynamic Properties of Rubberized Concrete, J. Constr. And Build. Matrls., 22, 939-947 (2008) 